\title{
Language Politeness in Syair Nasihat as a Representation of Sufi Da'wah Strategies
}

\author{
Asep Yudha Wirajaya ${ }^{1,}$, Bani Sudardi ${ }^{2}$, Istadiyantha ${ }^{3}$, Warto ${ }^{4}$ \\ ${ }^{1,2,3,4}$ Faculty of Cultural Science, Universitas Sebelas Maret, Surakarta, Indonesia \\ * Corresponding author. Email: asepyudha@staff.uns.ac.id
}

\begin{abstract}
The wujudiyah tragedy in Aceh in the 18th century had resulted in fundamental changes in Sufi teaching patterns. The murshids were very careful in rewriting the concepts of divinity. It is not uncommon for murshids to use symbolic poetry as a form of their politeness in representing God. In other words, $S N$ is a poem that is rich in Sufism teachings. The research method used is the philological method and the method of studying texts, especially concerning language politeness. The results of this study are forms of language politeness as a representation of Sufi da'wah in the archipelago. This is intended so that the Sufi doctrine contained in the $S N$ text is not "cut off" due to an erroneous interpretation. Thus, there will always be Sufi practitioners who can truly exist as a blessing for the universe and at the same time protecting Indonesia's diversity.
\end{abstract}

Keywords: da'wah, representation, strategy, Sufi, and Syair Nasihat

\section{INTRODUCTION}

The existence of poetry in the cultural treasures of the archipelago is a necessity [1]-[3]. Based on the classification made by Braginsky [4], it is known that there are also groups of religious poetry. These religious poems are useful as a medium or means used by scholars to spread Islamic teachings. However, the difference in perspective in the political field - due to the issue of power - is that the Islamic world of Nusantara in the 17th and 18th century was divided into two major groups, namely those of Sunni and Shi'a religions [5], [6]. The school mentioned first, is more dominant than the second, both politically and geographically. This reality has later contributed to the history of civilization in the archipelago, including during the "dark" episodes, namely the prohibition of the spread of the teachings of Sufism, wujudiyah, burning of wujudiyah murshid works, and the killing and even slaughter of followers of the sect. wujudiyah [7], [8]. As a result, this policy has caused fear for many circles, especially wujudiyah murshids because they are considered to be directly affiliated with the Shi'ah [7]-[9].. Besides, the followers of the wujudiyah sect were also victims of the regime's killings and massacres at that time.

The reality of the dominance of Sunni groups on the stage of the Islamic world allows it to also color the history of Islamic civilization in a larger portion than the Shi'a groups. Moreover, a schism had arisen from the very beginning, which later became "polarization" between the two groups. Thus, it is not surprising that it is not sufficient in the fields of theology (creed) and law (fiqh) that these two groups fight for an 'authoritative' position, but it could also be in terms of 'civilization' achieved. However, the wisdom of a Sufi teacher or murshid does not automatically make him think of taking revenge. At a time when many parties are afraid to write wujudiyah teachings in verse for fear of being seen as part of the teachings of a heretical order [10], [11]. Instead, he made works in which he taught students or salik to stick to the teachings of love as the manifestation of God's grace to all creatures on earth [7], [8], [12].

One of them is "Syair Nasihat" (hereinafter abbreviated to $S N$ ) which is full of wujudiyah Sufism messages. Based on the records of the SN text colophon, it is known that the manuscript was found on the island of Bali on April 10, 1857 AD. This is understandable considering that the tragedy of tyrannical domination had also occurred in Java, at the time of the murder of Sheikh Siti Jenar. Syekh Siti Jenar prioritizes Islam from the logic of makrifat (philosophy) rather than walisongo which prioritizes sharia (Islamic ritualism). Walisongo is the main advisor to the Demak Bintoro Palace, and therefore, the Walisongo version of mainstream Islam that was developed in the Islamic kingdom (Mashad, 2014). 
Syekh Siti Jenar's version of Islam is relatively limited, but not a few Majapahit figures are included in this sect, such as Ki Kebo Kenongo (brother of Kebo Kanigoro) who is none other than Ki Ageng Pengging. Syekh Siti Jenar left the board of trustees because he felt that the board of trustees was more concerned with state affairs (worldliness) than religious matters (afterlife) [13]. Thus, Siti Jenar's teaching of makrifat is more acceptable to Balinese Hindus because it places more emphasis on divine philosophy. Besides, substantially the Tri Hita Karana concept (the concept of harmony with God, fellow human beings, and the universe) is not much different from Islamic teachings. The concept of monotheism or the oneness of God is also emphasized with no boundaries (including the lines of worship) between the Creator, Sustainer, and Destroyer. He is Sang Hyang Widi Wasa or God Almighty, both in substance and in nature. As a result, Balinese (Hindu) ritualism is very different in style from Hinduism in its native land [13], [14]. Therefore, the existence of SN is interesting to be explored more deeply, especially in terms of politeness to be able to answer various problems of conflict with religious nuances that have recently become increasingly prevalent in the archipelago.

Also, the existence of $\mathrm{SN}$ as a part of the developed oral tradition has attracted Balinese people. Balinese people are accustomed to knowing kidung (tembang) in their daily life. Kidung (tembang) usually refers to traditional Javanese poetry which has a convention of syllables, number of lines, and rhythm. In other words, tembang consists of phonological elements (syllable convention) and intonation (number of lines and rhythm) [15], [16]. Arps [17] uses the term verse form to refer to this phenomenon because the tembang form determines the phonological, syntactic, and melodic aspects simultaneously when sung. The tembang tradition in Javanese society has a long history that stretches from the Hindu / Buddhist era to the beginning of Islam entering the archipelago [15]. Furthermore, Yalle (2003) states that in the tantric tradition, tembang is' a means to think or contemplate (an instrument of thought). This further confirms that the tembang or poetry has brought lingua to a transcendental direction. Moreover, SN was created within the sphere of Islamic influence

\section{LITERATURE REVIEW}

So far, language politeness is more focused on a choice of words to suit the situation and conditions [19]-[21]. That is, a speaker not only thinks about choosing the right word but also pays attention to the context surrounding the event of the word usage. So, good, precise, and following the context is quite a complicated matter [21], [22]. Of course, it is something that is not easy to learn. This is possible because a person does not only understand the language, but also the social and cultural values of the surrounding community [23]-[26] [52]. So far, we sometimes think that politeness is only by saying "please" and "thank you" in the right place, condition, and event [27]-[30].

This shows that language politeness does not only focus on word choice but also takes careful consideration of the socio-culture of the local community [20], [31], [32]. This concept is in line with the concept of politeness in a pragmatic perspective [19], [20]. So, someone who wants to talk to others, either directly or indirectly, must consider various options in the use of language, facial expressions, and body gestures [31], [32]. all of this is done solely to provide space to others for forms of respect and respect for fellow human beings. In other words, it is meant to show a friendly attitude to the other person or partner. Thus, the interlocutor will provide similar forms of appreciation and respect [24], [33], [34].

Considering the study of language politeness in the context of Malay poetry and communication is something that has just been done [19], [20], [22], [30], [35]. In this context, it is necessary to consider that the presence of SN which chronologically creates more than three different cultures and different cultures, it is interesting to look at the forms of politeness strategies used as part of their communication.

In this communication practice, it is necessary to master and understand the pragmatic and semantic theory [19]-[21], [36]. This is communication so that the communication process can run well, politely, and. In the communication process, a set of verbal and/or non-verbal symbols is used to represent feelings, values, ideas, and thoughts. Thus, communication that ignores the values of politeness, of course, will not work effectively [30], [37]. That is, politeness is one of the determining factors for the achievement of the communication process. So, the value of politeness used as a communication strategy has the same importance as the value of existing information [31], [32]. Based on this fact, pragmatic experts offer theoretical perspectives or linguistic models to keep the practice of communicating well with as few disputes as possible.

In the practice of communicating, we often find that certain words are considered very effective (have power) in influencing or changing human behavior [19], [20], [36]. Because psychologically, language 
has a very significant role in controlling or changing human behavior. This interaction is then used as a guide by communicators in disseminating Islamic treatises. This understanding is in line with the concept of "al-qawl" which when associated with da'wah, is related to "amr ma'ruf" [38], [39]. Thus, the context of communication is highly dependent on the language of "understanding" in communicating. This understanding is, of course, the language of communication in the corridor of truth [31], [32], [38].

\section{METHODS}

This study uses two methods, namely: general methods and special methods. The general method used in research is qualitative methods. Ratna [40] argues that qualitative methods are methods that utilize interpretive methods by presenting in the form of descriptions. In other words, this study uses a qualitative method that emphasizes the observation of phenomena and examines the substance of the phenomenon's meaning [41]. Based on the above opinion, this study presents the results of the analysis in the form of a description.

The special method used in this research is a method that refers to the theory being studied. The special method used is the philological research method. Based on the results of the inventory of the manuscripts, it is known that there are $5 \mathrm{SN}$ manuscripts with details. Two SN manuscripts are stored in the National Library of Indonesia, J1. Salemba Raya No. 28A Jakarta, with manuscript number Ml. 759A and Ml. 759B (from W. 232) [42], 1 manuscript stored at the Samparaja-Bima Cultural Museum with manuscript number A. 036 [43], 1 manuscript in the British Library with code EAP153 / 13/31 [44], and 1 manuscript stored at Orientabteilung Staatsbibliothek Zu Berlin with code Schoemann V 42 / PPN: 839014600 [45].

Since SN manuscripts are plural texts, the edition method used is the ledger method [46]. The selection of this basic method is based on the facts which show that there is one manuscript that has superior quality, both in terms of text completeness and legibility. Therefore, the main source manuscript in this research is the SN manuscript of the collection of the National
Library of Indonesia with the code ML 759 A. To examine this SN text, philological and codicological theories are used [3], [36], [46]-[48], while to examine language politeness in the communication process, politeness theory and da'wah communication theory is used [21], [31], [32]. In short, the theory of intertwining language politeness in the communication process will ultimately convey messages that are full of Sufi teachings. Then, these messages can be well received by the audience because they are conveyed through polite communication strategies [21], [31], [32], [36]. Finally, SN can be useful for murshids to convey and spread their teachings in a peaceful and acceptable context in all circles.

The research steps are as follows: taking inventory of the manuscripts containing $\mathrm{SN}$ texts by tracing the existing catalogs; (b) describe the manuscript containing SN text; (c) comparing texts that can be presented; (d) determine the foundation text; (e) compile an edit equipped with a critical apparatus; (f) reveals the politeness of the language contained in the SN text.

\section{RESULTS AND DISCUSSIONS}

One positive preference for this attractive politeness strategy can be identified through the respectful and self-effacing attitude of Malay Muslims toward those in power. This means that they always try to maintain good relations with those in power, despite their different beliefs. This can be understood because they think that the issue of guidance is God's prerogative, so the duty of a Muslim is to convey the truth, either through oral or good deeds or role models.

\subsection{Interesting Strategy}

Interesting strategies are used to influence the attitudes and thoughts of the public to accept and explore Islam. This interesting strategy is used, both directly and indirectly in SN texts. This can be seen in the selection of the da'wa communication strategy achieved by the author of the SN text as follows. He divided the discussion material into 5 sub-chapters, namely knowledge, worship, the essence of God, remembrance, and the unity of the people. this is shown in the following Table 1.

Table 1. Interesting Strategy of Politeness in $S N$ Text

\begin{tabular}{|c|c|c|c|}
\hline Strategy & Sub-discussion & Means & Action \\
\hline \multirow{5}{*}{ Direct } & Science & \multirow{5}{*}{ Sentence } & Requests, Suggestions, Orders, Restrictions \\
\hline & Worship & & Requests, Suggestions, Orders, Restrictions \\
\hline & The Essence of God & & Suggestions, Orders \\
\hline & Recitation & & Suggestions, Orders, Restrictions \\
\hline & The Unity of the People & & Suggestions, Orders \\
\hline
\end{tabular}


Based on the Table 1, it is known that the author applied an interesting strategy. This means that the author does not necessarily place the teachings of wahdat al-wujud in the early parts of the SN text. However, he first introduced knowledge and all its virtues as well as worship that must be performed by humans as well as servants of God Almighty. After that, the author introduces the essence of God which is the essence of the teachings of Wahdat al-wujud. The author also teaches good and correct dhikr procedures. As if it was used as some kind of basic guide for anyone interested in learning about wahdat al-wujud. In the end, the author also inserts an extraordinary moral message that every human being is obliged to protect life and every Muslim is also obliged to maintain the unity of the people as part of God's creatures. This message is in stark contrast to the various bad experiences that have been received and experienced by murshid wahdat al-wujud, who have experienced oppression, murder, expulsion, and even silencing as a form of prohibiting the spread of the teachings of tasawuf wahdat al-wujud [7], [12], [49]. This is the essence of the teaching of "love" exemplified by the murshid wahdat al-wujud. He never thought of taking revenge on those who had hurt him. Indeed, an example that is loaded with extraordinary wisdom values.

The SN text is a representation of the archipelago's intellectual assets that reintroduces the very fundamental teachings of Islam, namely Sufism. This teaching is very important for the search for a format to rebuild a peaceful Indonesian religion after the orthodox theological tradition found the status quo in fostering the ummah. Literal Islamic views often cause problems for the people and the state. For this reason, the ideas of 'urafa can be an alternative to religious and social life in the future. The 'urafa are not human beings who are always aloof from society. They are people who are physical with human society, but whose hearts are still one with God. They never neglect from dhikr to Allah. Therefore, they are known as true lovers [12].

\subsection{Direct Strategy}

The author of the SN text also applies a direct strategy in delivering $d a^{\prime} w a h$ materials related to Islamic concepts, such as the teachings of Wahdat alwujud. The Wahdat al-wujud which has been considered controversial in the archipelago is not because of its deviant teachings but is tarnished by negative provocations from religious authorities who want to maintain their power in the area of religious authority. This teaching is a way to save Muslims and mankind from religious teachings that find it difficult to find conformity with common sense and human objective views [12], [49].
This is in line with Nasr's statement [5], [6] that Sufism is capable of reaching the goal of mystical craving, a goal which mankind is always looking for because it resides in the depths of humanity's existence itself. As long as man is a human being, this mystical quest will continue in the long stretch of episodes of human life. That is the ontological awkwardness that anyone longing for spiritual enlightenment dreams of. This can be seen through the $S N$ Text excerpt as follows.

Data 3:

if the book has been studied

sail too you go on the pilgrimage

many women are willing

because you know the Koran

father and mother are very in love

because you according to the word

which one is the meaning

to your brother wealth is divided

mind the language you throw away

so love everyone //

your lust against the war

that's a very fierce enemy [50, pp. 5-6]

From the quote "if the book has been studied/sailed, you should go on a pilgrimage", there is an element of politeness related to requests and suggestions, namely by using the word "if". The use of this word indicates that the request and suggestion that Muslims know first, before fulfilling the fifth pillar of Islam, namely the pilgrimage. This is understandable considering that the Sufis adhere to the physical aspects of the Qur'an and the Sunnah, as well as fully adhere to the real rules of the Hajj. Besides, they also know about wara' (keeping away from sin, immorality, and things of syubhat) and fear on the outer side and piety on the inner side. Therefore, they appealed to the Muslims to prepare themselves in advance with the knowledge and piety that truly piety so that their goals and intentions in Hajj can truly bring the feeling of meeting Allah SWT. This meeting, of course, can never take place, except at the top of the spiritual ladder, because of the tajalli of divine emanations. Thus, those who want to achieve their goal or go on pilgrimage will reach their goal.

So, Hajj is not just visiting the Kaaba and other holy places without understanding and realizing the true meaning of Hajj. Many Muslims consider that the pilgrimage is limited to a tour of several historical places, without any emotional ties in their souls. These holy places have deep religious meaning. If the temple of Allah is especially glorified and glorified, then a person who performs a pilgrimage to Allah SWT. with a pure heart will reveal the essence of his rububiyah. 
Thus, the deepening of the meaning of Hajj will be found through the following three phases. The first phase, fulfilling the obligation of hajj as ordinary people do it through the senses only; the second phase, relies on the use of the Sufistic Mujahada Method and the Spiritual Riyadhah; the third phase, letting go of all attachments to the senses, immersing in Allah SWT. and the lights of Allah the Mighty. In other words, he will come to a level of wisdom [6], [51].

Thus, through Hajj, a Muslim will pass through the level of the Sufistic ladder from senses to reason, then to the heart. This achievement requires continuity of the mujahada to prepare the ability to witness and monotheism. This situation can only occur when the salik denies the many, which are sensed. At that time, what he witnessed was al-Haqq and His tajalli. In other words, he has reached the highest level of Sufistic monotheism [6], [51]. Therefore, the importance of knowledge becomes something that is emphasized repeatedly to the salik. This can be seen in the following quote.

Data 11:

that's why the poor say

the science you demand then treasure

all of us die

a good name so a story [50, p. 10]

Without adequate mastery of knowledge, a Muslim will only be trapped in forms of religious ritual which are dry and far from their spiritual meaning. As a result, he will feel tired, bored, and do not get peace and peace of mind. Allah SWT. always promises tranquility and peace of mind as a bonus from the worship being carried out. This can be seen in the following quote.

Data 23:

also have tekalang fish answer the word from behind the enemy is very my heart bridle your worship is less of a debt

[50, p. 48]

Based on this quote, a salik who has truly mastered the science of Sufism will see that prayer is a form of worship that includes all the signs for the Sufistic road, with all its maqamat, from beginning to end. Thaharah can be likened to repentance; both of them are very important acts of preparation. Facing the qibla is synonymous with murshid; both are related to the will of a salik. Standing in prayer and all demands that include will, struggle, sabra, and distress, is equated with mujahada an-nafs (inner struggle to cleanse the soul). Reading the Qur'an is equated with continuity of remembrance because the verses of the Qur'an are the best remembrance. Likewise, with bowing in the prayer which can be likened to submitting to Him. Based on this concept, a salik travels in prayer and goes through various kinds of stations that will lead him to the maqamat almahabbah [51]. However, if a Muslim does not know his knowledge, then praying will only abort the obligation, without ever reaching the true meaning of the prayer he is doing.

\subsection{Indirect Strategy}

The author of the SN text also applies an indirect strategy when delivering materials related to the concept of wahdat al-wujud. This is so that the teaching can be accepted by the wider community after the initial presentation was preceded by the description of the Islamic counselor as a gift of the universe. The use of this strategy is shown in the following Table 2.

Table 2. Indirect Strategy of Politeness in $S N$ Text

\begin{tabular}{|l|l|c|l|}
\hline Strategy & \multicolumn{1}{|c|}{ Metaphor } & \multicolumn{1}{c|}{ Means } & \multicolumn{1}{c|}{ Action } \\
\hline \multirow{3}{*}{ Indirect } & Fish & \multirow{2}{*}{ Lexical } & Requests, Suggestions, Orders, Restrictions \\
& Coconut & Suggestions, Orders \\
\cline { 2 - 3 } & Light & Suggestions, Orders \\
\hline
\end{tabular}

In applying this strategy, it seems that the author is more dominant in playing the fish symbol to convey the teachings of Wahdat al-wujud. Based on available data, at least 13 fish figures were found to be used to illustrate the analogy of the application of these teachings. This can be seen in the following Table 3 .

Table 3. Fish Names in $S N$ text

\begin{tabular}{|l|l|l|}
\hline \multicolumn{1}{|c|}{ Freshwater } & \multicolumn{1}{c|}{ Seawater } & \multicolumn{1}{c|}{ Brackish water } \\
\hline Tambra & Silar & Bahung \\
Sepat & Kerapu & Belanak \\
Lundu/Keting & Tekalang & Kakap \\
Lele & Kakap & \\
Gurami & & \\
Gabus & & \\
\hline
\end{tabular}


Based on the Table 3, at least it can be said that the author of the $S N$ text is a murshid figure who truly understands the socio-cultural situation of the community which is the target of his preaching. This can be seen from the classification of fish used in the text to represent freshwater - brackish water seawater. That is, through fish figures who are so close to the nature and culture of the fishing community or the coast, it is hoped that the teachings of Sufism conveyed can be received properly and correctly. This can be seen in the $S N$ text excerpt as follows.

Data 54:

indeed, there are lots of fish now

lack of knowledge and charity

very good at talking about people

unconscious on his face fragrant $[50$, p. 60]

Based on this quote, the analogy can be said to be the most favored means by Sufis in expressing their thoughts, without having to offend, humiliate, or hurt others directly. This is in line with what has been done by Ibn Arabi and Hamzah Fansuri. Sufis always see all reality incarnate as a symbol of the nature of reality. The essence of reality lies behind manifest realities. Therefore, the Sufis always advocate a representation of reality, that is, the realities must be returned to their original meaning so that the True Reality can be found.

In other words, the analogy is used as the main guide by Sufis in teaching and spreading their metaphysical teachings. This is also part of the indirect strategy in da'wa communication. If the murshids are not correct in giving analogies, then the whole metaphysical teaching will be misunderstood. Hence, analogy accuracy is a measure of the quality of a murshid [12]. So, accuracy in the understanding analogy is also an important principle in understanding the essence of the metaphysical teachings of the Nusantara murshids.

\section{CONCLUSION}

Based on the previous description, it can be concluded that the use of interesting strategies contained in the SN text is intended to be able to influence the attitudes and views of the audience to accept Islam. To support these objectives, direct and indirect strategies are also implemented. An interesting strategy is carried out by dividing the discussion material into 5 sub-chapters, namely knowledge, worship, the nature of God, dhikr, and the unity of the people. This means that the author tries to direct his audience by first explaining science. Armed with knowledge, then the author invites the audience to re-evaluate the religious worship rituals that have been carried out so far. Then, by improving the ritual, it is hoped that the salik will be able to know God Almighty. Then, salik applies these teachings as a form of grace for the universe. The direct strategy is carried out by using elements of politeness, such as those related to requests and suggestions. The indirect strategy is used by using an analogy which is used as a means of preaching the Sufis. The analogy used in the SN text is dominated by fish symbols. This is understandable considering the socio-cultural conditions of the people in coastal areas are easier to accept and adapt to new cultures or teachings.

\section{ACKNOWLEDGMENT}

This article was completed properly because of the assistance of very crucial data on the development of Sufism in the Aceh Sultanate during the time of Sheikh Abdul Rauf as-Singkili. Therefore, allow the author to express his gratitude to (1) Prof. Dr. Oman Fathurahman, M.Hum. (Syarif Hidayatullah State Islamic University); (2) Dr. Abdullah M, Hum. (Diponegoro University), who was also willing to provide materials related to the development of the spread of the Wujudiyah tarekat teachings on the island of Java, especially the Cirebon Sultanate. May God the Merciful and the Most Merciful will reward all his good deeds with the best. Acknowledgements and appreciation to University Centre of Excellence Javanologi for Javanese Traditions Universitas Sebelas Maret.

\section{REFERENCES}

[1] V. Braginsky, "Meaning of the sound: Magic and sufi mysticism in the phonic structure of the Malay charm and chant," Indones. Malay World, 2006.

[2] A.Y. Wirajaya, et. al. Textology: Studying the Treasures of Classical Malay Literature. Surakarta: Library Oasis, 2020.

[3] A.Y. Wirajaya, Poetic Aesthetics of Classical Malay Literature. Surakarta: Library Oasis, 2019.

[4] V. Braginsky, The Heritage of Traditional Malay Literature: A Historical Survey of Genres, Writing and Literary Views. Leiden: KITLV Press, 2004.

[5] S.Y. Nasr, et. al. Sufi Heritage: Classical Persian Sufism from Beginning to Rumi (700 - 1300). Yogyakarta: Pustaka Sufi, 2002. 
[6] S.H. Nasr, Sufism: Past and Present. Yogyakarta: IRCiSoD, 2020.

[7] A. Hadi, Oppressed Sufism: A Hermeneutic Study of Hamzah Fansuri's Works. Jakarta: Paramadina, 2001.

[8] M.W. Yahya, Uncovering the Spiritual Secret of Sheikh Abdul Muhyi: Tracing in the Footsteps of Archipelago Sufi Figures in the XVII \& XVIII Century. Bandung: Refika Aditama, 2007.

[9] D. Lombard, Kingdom of Aceh: the era of Sultan Iskandar Muda (1607 - 1636). Jakarta: Popular Libraries Gramedia - Forum Jakarta-Paris - École française d'Extrême-Orient, 2014.

[10] Syafrial, Hadi Rumadi, Oki Rasdana, "The Aesthetic of Mantra as Medical Treatment in Malay Riau," in International Seminar and Annual Meeting BKS - PTN West Region, Fields of Language, Literature, Arts, and Culture, 2018.

[11] N. Setyowati, et. al. "Islamic Eschatology in Syair Ibarat and Khabar Kiamat," SMaRT J. Soc. Relig. Tradit. Stud., vol. 3, no. 2, 2017.

[12] Miswari, Wahdah al-Wujud: Concept of Unity of Being between Servant and God according to Hamzah Fansuri. Yogyakarta: Basabasi, 2018.

[13] D. Mashad, Balinese Muslims: Recovering Lost Harmony. Jakarta: Pustaka Al-Kautsar, 2014.

[14] D.S. dan Y.I. Amellia, Bali 1842: Lets Over Balie en Deszelfs Bewoners. Jakarta: Perpustakaan Nasional Republik Indonesia, 2012.

[15] W. Widodo, Javanese Song Mantra: Parsing the Lingual to the Transcendental. Malang: UB Press, 2018.

[16] J.J. Ras, Society and Literature in Java. Jakarta: Yayasan Obor Indonesia, 2014.

[17] B. Arps, Tembang in Two Tradition: Performance and Interpretation of Javanese Literature. London: SOAS - University of London, 1992.

[18] R.A. Yalle, Explaining Mantras. New York: Routledge, 2003.

[19] J. Holmes, An Introduction to Sociolinguistics. London: Longman, 2001.

[20] G. Leech, The Principle of Pragmatics. Harlow: Longman Group Limited, 1983.

[21] M. Leezenberg, Contexts of Methaphor: Current Research in the Semantics/Pragmatics Interface:
Volume 7. Amsterdam: Elsevier, 2001.

[22] K. Grainger, "We're not in a club now": A neoBrown and Levinson approach to analyzing courtroom data," J. Politeness Res., vol. 14, no. 1, pp. 19-38, 2018.

[23] Alafnan, M, "Politeness in Business Writing: The Effects of Ethnicity and Relating Factors on Email Communication," Open J. Mod. Linguist., vol. 4, pp. 275-289, 2014.

[24] S. Van der Bom, I., \& Mills, "A discursive approach to the analysis of politeness data," $J$. Politeness Res., vol. 11 (2), no. Special Issue: Tenth Anniversary Issue, pp. 179-206, 2015.

[25] M.N. Jamian and S. B. Md Radzi, "Traditional Malay literature and the generation of knowledge," in Pertanika Journal of Social Sciences and Humanities, 2016.

[26] N. Chojimah, "Refusal and Politeness Strategies in Relation to Social Status: A Case of facethreatening Act among Indonesian University Students," Theory Pract. Lang. Stud., vol. 5, no. 5, pp. 906-918, 2015.

[27] S.H. Etae, Suhaila \& K. Pramela, "Politeness Strategies by Thai EFL Tertiary Learners in an Online Forum," Pertanika J. Soc. Sci. Humanit., vol. 24, no. S, pp. 67-80, 2016.

[28] A. Izadi, "Politeness in spoken review genre: Viva voce context," Pertanika J. Soc. Sci. Humanit., vol. 21, no. 4, pp. 1327-1346, 2013.

[29] A. Izadi, "Over-politeness in Persian professional interactions,” J. Pragmat., vol. 102, pp. 13-23, 2016.

[30] L.N. and T.S. Yaqin, "Politeness Strategies of the Pembayun(s) in The Bride- Kidnapping Practices of Sasak Culture," Pertanika J. Soc. Sci. Humanit., vol. 28, no. 1, pp. 89-102, 2020.

[31] K. Suhandang, Da'wah Strategy: Application of Communication Strategies in Da'wah. Bandung: Remaja Rosdakarya, 2014.

[32] W. Ilaihi, Da'wah Communication. Bandung: Remaja Rosdakarya, 2013.

[33] M.K. \& J.H.S. Bayanuddin, "The Directive Speech Acts Used in English Speaking Class," IJER, vol. 1, no. 2, pp. 91-97, 2016.

[34] S. Eshginejad and M.R. Moini, "Politenes Strategies Used in Text Messaging: Pragmatics Competence in Asymmetrical Power Relation of Teacher - Student," SAGE, vol. January-Ma, pp. 


\section{$1-13,2016$}

[35] S.M.R. Adel, "A Qualitative Study of Politeness Strategies used by Iranian EFL Learners in a class blog," J. Lang. Teach. Res., vol. 4, no. 1, pp. 47-62, 2016.

[36] Brown P. \& Levinson S.C., Politeness; Some Universals in Language Usage. Cambridge: Cambridge University Press, 1987.

[37] T. Yaqin, Lalu Nurul \& Shanmuganathan, "The non-observance of Grice's Maxims in Sasak," $3 L$ Lang. Lit., vol. 24, no. 2, 2018.

[38] Hamka, Modern Sufism: Happiness is Close to Us - It is within Us, 12th ed. Jakarta: Republika Penerbit, 2020.

[39] K. Hidayat, Understanding the Language of Religion: A Hermeneutic Study. Jakarta: Paramadina, 1986

[40] N. K. Ratna, Theories, Methods and Techniques of Literary Research from Structuralism to Post structuralism: The Perspective of narrative discourse. Yogyakarta: Pustaka Pelajar, 2015.

[41] N. Mohamed, Z.M., Abdul Majid, A.H., \& Ahmad, Tapping New Possibility in Accounting Research, in Qualitative Research in Accounting, Malaysian Case. Kuala Lumpur: Universiti Kebangsaan Malaysia, 2010.

[42] T.E. Behrend, et al., Main Catalog of Archipelago Manuscripts Volume 4: National Library of the Republic of Indonesia. Jakarta: Yayasan Obor Indonesia dan I'Ecole Francaise d'Extreme Orient, 1998.
[43] S.M.R. dan M. Salahuddin, Bima Manuscript Catalog: Collection of Samparaja Cultural Museum. Mataram: Museum Samparaja Bima, 2007.

[44] Anonim, "Syair Nasihat Pengajaran untuk Memelihara Diri [1349] | Endangered Archives Programme." [Online]. [Accessed: 11-Jul-2020].

[45] Anonim, "Start - Oriental manuscripts at the State Library of Berlin." [Online]. [Accessed: 11-Jul-2020].

[46] E. Djamaris, Philology Research Methods. Jakarta: Monasco, 2002.

[47] O. Fathurahman, Indonesian Philology: Theory and Method. Jakarta: Prenadamedia Group and UIN Jakarta, 2015.

[48] A. Ikram, Introduction to Philological Research. Jakarta: Archipelago Textbook Society, 2019.

[49] Zaprulkhan, Tasawuf Science: A Thematic Study. Jakarta: Rajawali Pers, 2017.

[50] Anonim, Syair Nasihat. Jakarta: Perpustakaan Nasional Republik Indonesia, 1857.

[51] K.A.A. Karam, The Nature of Worship according to Ibn 'Arabi: Understanding the Meaning and Wisdom of the Pillars of Islam. Tangerang Selatan: Alifia Books, 2020.

[52] M. Ridwan, G.L. Dewi \& B. Mohamad, "The Attitude of Egyptian Arabic Speakers Towards Standard Arabic and Egyptian Arabic", Advanced Science Letters, Vol. 22, No. 12, pp. 4374-4377, 2016 